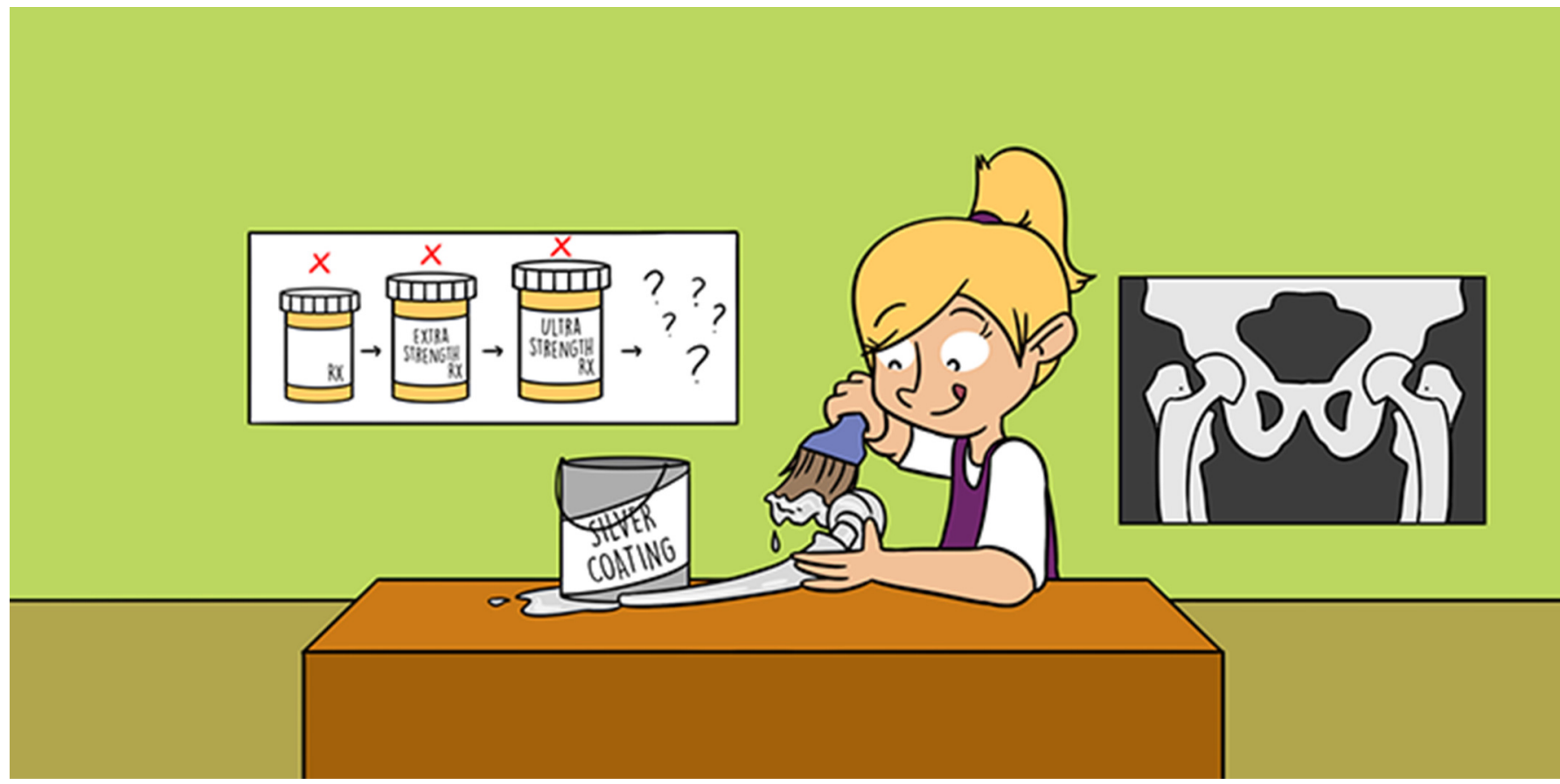

\title{
DANGEROUS SLIMES: HOW BACTERIAL BIOFILMS MAKE YOU SICK AND HOW TO COMBAT THEM
}

\section{Hervé Poilvache ${ }^{1,2}$ and Françoise Van Bambeke ${ }^{1 *}$}

${ }^{1}$ Pharmacologie Cellulaire et Moléculaire, Louvain Drug Research Institute, Brussels, Belgium

${ }^{2}$ Neuromusculoskeletal Lab, Institut de Recherche Expérimentale et Clinique, Université Catholique de Louvain, Brussels, Belgium

\section{YOUNG REVIEWERS:}

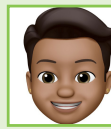

NAVIN

AGE: 13

RANJANA

AGE: 14

TALAL

AGE: 14

Yes, we can house dangerous slimes called biofilms in our bodies. They can cause severe infections anywhere in our bodies. They contain bacteria hidden and hibernating in a protective matrix. This makes them really difficult to treat. They like to stick on implanted material like prostheses or catheter. They can also persist on your teeth, in your ears, even sometimes in your lungs. Luckily, researchers are very aware of this problem. They are experimenting with diverse solutions to try to destroy these biofilms. Are you curious about their brilliant ideas? Then follow us to learn more about how biofilms make you sick and how we try to combat them.

Bacteria are small living organisms. They are much more numerous than humans on our planet. There are more bacteria in $1 \mathrm{ml}$ of water than humans on Earth! They can inhabit the environment, but also the human body. Facing such a big world, they need to find strategies to survive. Do you know the saying "Together, we are stronger"? Microbes know it! To better survive, most bacterial species are able 


\section{Figure 1}

A few examples of biofilm-related infections. In red, those developing on tissues in our body. In purple, those developing on implanted material.

\section{MATRIX}

A mixture of substances in which bacteria are embedded and support the global architecture of the biofilm

1 https://kids.frontiersin org/article/10.3389/ frym.2016.00014

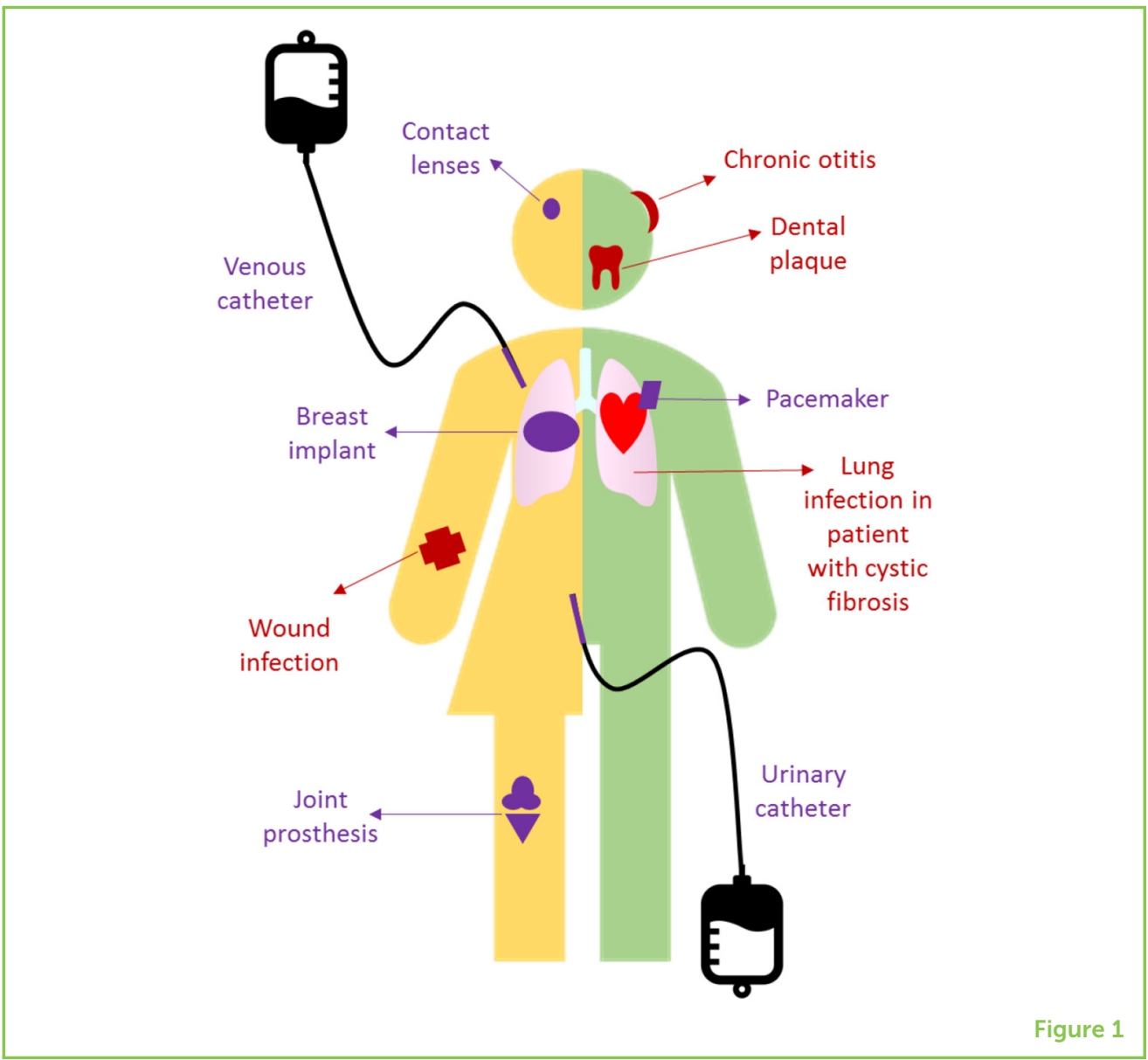

to gather in communities called biofilms ${ }^{1}$. In biofilms, bacteria play hide-and-seek. They produce a protective blanket called a matrix. It contains sugars, proteins, and nucleic acids [1]. Biofilms are thus very different from what we call "planktonic cultures." These consist of isolated bacteria freely swimming in a liquid, like plankton in the sea. In the environment, biofilms form everywhere: on pipelines, boat hulls, rocks, or even in hot water springs. In the human body, they can attach to organs and, more easily, on implanted material. If they contain pathogenic bacteria, they are a major cause of chronic infections.

\section{WHY ARE BIOFILMS IMPORTANT IN HUMAN PATHOLOGIES?}

Bacteria love to attach everywhere in our bodies [2] (Figure 1). Do you know about dental plaque? This slimy substance forms on your teeth between visits to the dentist. It contains a mix of bacteria and proteins from your saliva. You can remove it by regularly brushing your teeth. Otherwise, the bacteria inside the plaque will consolidate the biofilm. In the end, you will suffer from inflammation of the gums and dental cavities. Good hygiene and frequent care by a dentist help you keep your teeth in good health! Biofilms can also form in many other places and cause chronic infections. These infections may improve 


\section{ANTIBIOTIC}

A substance that is capable of preventing bacterial growth, or even more, to kill bacteria.

2 https://kids.frontiersin. org/article/10.3389/ frym.2019.00106

\section{CATHETER}

Thin tube that can be inserted in the body to inject drugs in the blood or to drain fluids (urine or pus, for example).

\section{DRAIN}

Tube implanted to remove fluid collections from the body (for example at the end of a surgical procedure).

\section{METABOLISM}

The whole chain of chemical reactions that occur in a cell and support life (production of energy, synthesis of molecules needed as building blocks for the cell).

3 https://kids.frontiersin. org/article/10.3389/ frym.2019.00045

\section{ANTIBIOTIC} RESISTANCE

Acquisition by bacteria of a mechanism making them insensitive to antibiotics (for example, destruction of the antibiotic, modification of the antibiotic target). when you take an antibiotic. But they restart soon after you stop the treatment. A few examples of such infections? Chronic infections of the ear (otitis) if you often go to the swimming pool, or pulmonary infections in children with a genetic disease called cystic fibrosis ${ }^{2}$. Poor children! The mucus in their lungs is slimy and bacteria find it very comfortable. Such infections are difficult to get rid of. This is a big problem. The patient will undergo extended and frequent antibiotic treatments, but the bacteria will defend themselves and evolve. Eventually, they become resistant to the treatment and in the end, antibiotics will no longer work to fight off the infection at all.

Most devices used in medicine also offer perfect shelters for the development of biofilms. Think about your last visit to your grandparents at the hospital. They probably had intra-venous catheters to deliver medicine in their blood or other drains. Maybe they also had a joint prosthesis implanted in the hip or knee when their own joint was too painful. These artificial surfaces are easily colonized by bacteria. They strongly bind to them. Then, they quickly start to multiply and produce a matrix. On these devices, biofilms grow in very complex structures. Bacteria will gradually adapt to their new environment. They will no longer respond to antibiotics anymore. In the end, the only option for doctors will be to remove the device and replace it with a new one, if possible. Of course, it is easy when the device is a simple catheter. But removing an implant, such as a hip or a knee prosthesis, is a complex procedure. It often requires multiple surgeries and your grandparent will probably not like that very much!

\section{WHY ARE BIOFILM-RELATED INFECTIONS TOLERANT TO ANTIBIOTICS?}

A biofilm is like a well-protected burrow where bacteria hibernate. The matrix creates a barrier against antibiotics. But this defensive barrier also limits the penetration of oxygen and food. Bacteria located in the deepness of the biofilm will start starving. They slow down their metabolism $^{3}$, as if they were sleeping (Figure 2, left panel). A sleeping soldier is easier to kill than a vigilant one. But this does not apply at all to bacteria! Many antibiotics only act on bacteria that are actively multiplying and this cannot happen when the bacteria are sleeping in the biofilm. This phenomenon is called "tolerance" to antibiotics. Contrary to antibiotic resistance, tolerance is reversed when bacteria leave the biofilm [3]. But tolerance also contributes to treatment failure. We need 1,000 times more antibiotics to kill bacteria in biofilms than in planktonic cultures. The antibiotic prescribed by your doctor will therefore not work! Except if you take 1,000 more pills ... but are you really willing to swallow that many pills? And even if you could, such high doses would make you very sick! Would you like to have a very bad stomach ache, diarrhea, or headache? Or even worse, would you like to destroy your kidneys, liver, or blood cells? No! 


\section{Figure 2}

(Left) Why biofilms are tolerant to antibiotics. (Right) Strategies to combat biofilm-related infections.

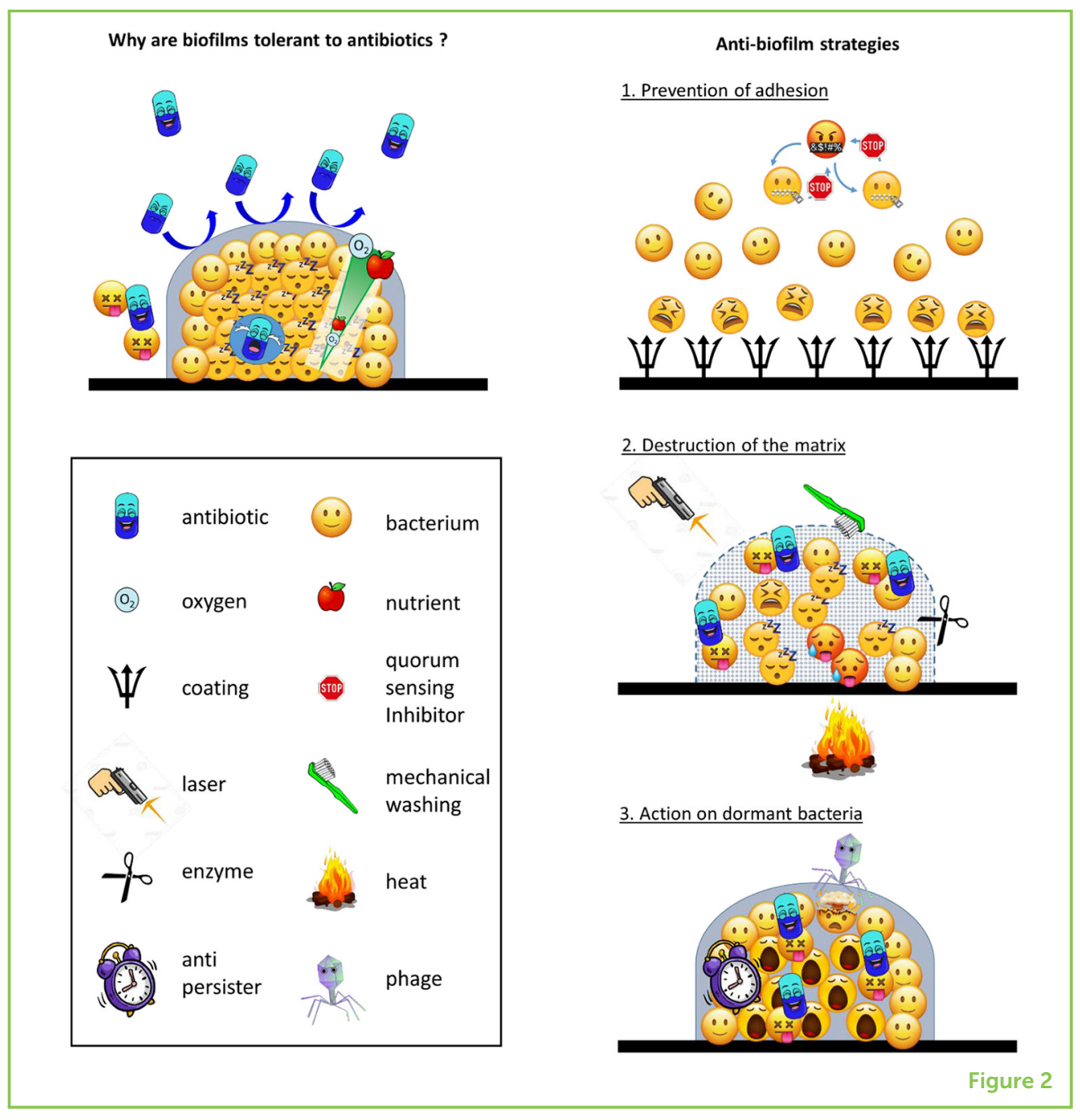

\section{WHICH THERAPEUTIC STRATEGIES CAN WE USE AGAINST BIOFILMS?}

You now understand that antibiotics do not work against biofilms. We need to imagine other strategies to fight biofilms. This is one of the main topics of intensive research at the moment [4]. You can think of three types of approaches (Figure 2, right panels).

First, prevention is better than a cure! We can try to prevent biofilm formation. This is a good idea for biofilms forming on implanted material. We can coat the surface of the implant with substances that prevent the attachment of bacteria. You can get this effect with silver coating, for example. With this noble metal in your body, you are now very precious! We can also fill the implanted device with high amounts of antibiotics. They are thus ready to act on bacteria before they start to sleep. For example, we can use a type of cement, loaded with antibiotic beads, to repair a bone fracture. We can also wash a catheter with a concentrated antibiotic solution. Most of these approaches are already used in clinics. Alternatively, we can interfere with the communication 


\section{ENZYME}

Protein capable of transforming one molecule in another one, for example in degradation products.

system bacteria use. It is called quorum sensing [5]. It consists of molecules produced by bacteria and is sensed by their neighbors, as if they were smelling a nice perfume. Without your cell phone, you cannot call your friends. Without quorum sensing, bacteria cannot find each other to start building the biofilm.

Second, we can try to destroy the matrix. This should help the antibiotic to reach the hidden bacteria. This goal can be achieved with enzymes. They will cut the substances present in the matrix into small pieces, just like if you were to unknit your pullover-you are more exposed and fragile, are not you? We can also wash the biofilm with a high-pressure Karcher (a high pressured cleaning tool). Or we can try other impressive techniques, like laser shocks, electrical currents, or even heat. This may look like science-fiction! And somehow barbarous and painful! But be aware that some of these techniques are already used by your dentist or by your surgeon while you are sleeping in the operating room...

Third, we can try to wake the sleeping bacteria up. This is not an easy task. We need to discover "anti-persister" molecules. These will help antibiotics to kill sleeping bacteria. The first anti-persister molecule was discovered only a few years ago [6]. It activates an alarm system in bacteria. When the bell rings, it is time to wake up! Other anti-persisters make holes in the bacterial envelope. What will happen if you open all the windows in your home? On the one side, fresh air from outside will enter the room and wake you up. This means that bacteria are not sleeping anymore. On the other hand, pollens could enter and make your eyes itch if you are allergic to them. For bacteria, it means that antibiotics could enter the cell to harm them. These anti-persisters are still being tested in laboratories. They are not yet used to cure people. Another amazing approach uses biological weapons. Bacteriophages [7] are viruses of bacteria. They make bacteria sick but not humans. Some of them also produce enzymes that can destroy the matrix. That means that they can hit two targets with one shot!

\section{WHAT ABOUT THE FUTURE?}

Most of these new strategies are still under development. A lot of work is required to make sure that they are active and work right. Another concern is the risk that these strategies could be toxic. However, we are making progress at a steady pace. Some treatments have recently been tried in patients! For example, bacteriophages have been used, with success, to treat an infant with a severe liver infection.

Are you interested in joining a team of researchers to work on these topics? We are looking forward to seeing you in our laboratory in the near future!

You can find more information in this Young Minds Article $[5,7]$. 


\section{ACKNOWLEDGMENTS}

The authors thank Camille, Charlotte, and Valentine (12-14 years old) for having read and commented on this paper.

\section{REFERENCES}

1. Costerton, J. W., Stewart, P. S., and Greenberg, E. P. 1999. Bacterial biofilms: a common cause of persistent infections. Science 284:1318-22. doi: 10.1126/ science.284.5418.1318

2. Lebeaux, D., Ghigo, J. M., and Beloin, C. 2014. Biofilm-related infections: bridging the gap between clinical management and fundamental aspects of recalcitrance toward antibiotics. Microbiol. Mol. Biol. Rev. 78:510-43. doi: 10.11 28/MMBR.00013-14

3. Yan, J., and Bassler, B. L. 2019. Surviving as a community: antibiotic tolerance and persistence in bacterial biofilms. Cell Host Microbe 26:15-21. doi: 10.1016/ j.chom.2019.06.002

4. Suresh, M. K., Biswas, R., and Biswas, L. 2019. An update on recent developments in the prevention and treatment of Staphylococcus aureus biofilms. Int. J. Med. Microbiol. 309:1-12. doi: 10.1016/j.ijmm.2018.11.002

5. Costantino, V., and Esposito, G. 2018. Do you know that microbes use social networks? Front. Young Minds 6:31. doi: 10.3389/frym.2018.00031

6. Conlon, B. P., Nakayasu, E. S., Fleck, L. E., LaFleur, M. D., Isabella, V. M., Coleman, $\mathrm{K}$., et al. 2013. Activated ClpP kills persisters and eradicates a chronic biofilm infection. Nature 503:365-70. doi: 10.1038/nature12790

7. Gutiérrez, D., Fernández, L., Martínez, B., Rodríguez, A., and García, P. 2016. Bacteriophages: the enemies of bad bacteria are our friends! Front. Young Minds 4:30. doi: $10.3389 /$ frym.2016.00030

SUBMITTED: 16 October 2019; ACCEPTED: 09 April 2020; PUBLISHED ONLINE: 15 May 2020.

EDITED BY: Michel Goldman, Institute for Interdisciplinary Innovation in Healthcare (I3H), Belgium

CITATION: Poilvache H and Van Bambeke F (2020) Dangerous Slimes: How Bacterial Biofilms Make You Sick and How to Combat Them. Front. Young Minds 8:62. doi: 10.3389/frym.2020.00062

CONFLICT OF INTEREST: The authors declare that the research was conducted in the absence of any commercial or financial relationships that could be construed as a potential conflict of interest.

COPYRIGHT @ 2020 Poilvache and Van Bambeke. This is an open-access article distributed under the terms of the Creative Commons Attribution License (CC BY). The use, distribution or reproduction in other forums is permitted, provided the original author(s) and the copyright owner(s) are credited and that the original publication in this journal is cited, in accordance with accepted academic practice. No use, distribution or reproduction is permitted which does not comply with these terms. 

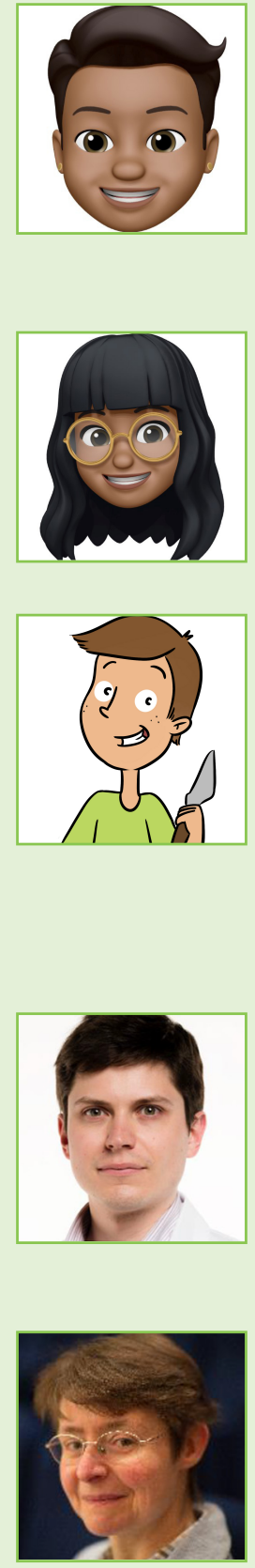

\section{YOUNG REVIEWERS}

\section{NAVIN, AGE: 13}

I am interested in the medical field and aspire to become an anesthesiologist in the future. I enjoy reading and drawing cartoons. I have been playing ice hockey and love being on the rink. Tennis, swimming, and cross-country is also my favorite sports. I love eating anything that is vegetarian. I want to contribute to my community in any way I can and make a positive change.

\section{RANJANA, AGE: 14}

I love science and am especially into medicine. I am passionate about health and wellness. I enjoy reading and watching heist movies. I love spending time in labs, researching, and learning. I would like to learn more languages; right now, I can speak three. I hope to travel to more countries in the future!

\section{TALAL, AGE: 14}

I am a 14 years old boy who lived in England and had all my education there. I have recently moved back to Belgium. I play a lot of sport including tennis, football, and hockey. I am also interested in sciences and would be inspired to be a doctor in the future.

\section{AUTHORS}

\section{HERVÉ POILVACHE}

I am a medical doctor from the Université Catholique de Louvain (Brussels, Belgium), I have begun a specialization in Orthopedic Surgery, and I am currently a Ph.D. student in Pharmaceutical and Biomedical Sciences at the same university. My main research interest is the development of new ways to treat biofilm-related infections in the orthopedic field.

\section{FRANÇOISE VAN BAMBEKE}

I am a pharmacist passionate about research on antibiotics and bacteria. After a doctoral thesis and a visit at the Pasteur Institute (Paris, France), I came back to the Université Catholique de Louvain (Brussels, Belgium) where I work for the Fonds de la Recherche Scientifique with a team of researchers. We are trying to understand why antibiotics are not always active on bacteria and to find solutions to restore their effectiveness. I also teach the proper use of medications to future pharmacists. *francoise.vanbambeke@uclouvain.be 